\title{
A new species of the genus Formosotoxotus Hayashi, 1960 from China, with additions to the description of Agastopbysis meiyingae Miroshnikov, 2014 (Coleoptera: Cerambycidae)
}

\author{
Новый вид рода Formosotoxotus Hayashi, 1960 из Китая \\ с дополнениями к описанию Agastophysis meiyingae \\ Miroshnikov, 2014 (Coleoptera: Cerambycidae)
}

\author{
Alexandr I. Miroshnikov ${ }^{1}$ \& Mei-Ying Lin ${ }^{2}$ \\ А.И. Мирошников ${ }^{1}$, М. $\Lambda и \mathrm{H}^{2}$
}

\footnotetext{
${ }^{1}$ Russian Entomological Society, Krasnodar, Russia. E-mail: miroshnikov-ai@yandex.ru Sochi National Park, Moskovskaya str., 21, Sochi, Krasnodar region 354002 Russia.

${ }^{1}$ Русское энтомологическое общество, Краснодар, Россия.

Сочинский национальный парк, ул. Московская, 21, Сочи 354002, Краснодарский край, Россия

${ }^{2}$ Key Laboratory of Zoological Systematics and Evolution, Institute of Zoology, Chinese Academy of Sciences, 1 \# Beichen West Road, Chaoyang, Beijing 100101, China. E-mail: linmeiying@ioz.ac.cn
}

KEY WORDS: Coleoptera, Cerambycidae, Apatophyseini, Formosotoxotus, new species, China, Tibet, Agastophysis meiyingae, holotype, new data.

КЛЮЧЕВЫЕ СЛОВА: Coleoptera, Cerambycidae, Apatophyseini, Formosotoxotus, новый вид, Китай, Тибет, Agastophysis meiyingae, голотип, новые данные.

ABSTRACT. A new species Formosotoxotus gressitti sp.n. from Tibet, China is described. New data on the holotype of Agastophysis meiyingae Miroshnikov, 2014 are given.

РЕЗЮМЕ. Описывается новый вид Formosotoxotus gressitti sp.n. из Тибета (Китай). Приведены новые данные о голотипе Agastophysis meiyingae Miroshnikov, 2014.

\section{Introduction}

Until recently Formosotoxotus auripilosus (Kano, 1933), an insular species from Taiwan, was the only known representative of this genus in the fauna of China [Ohbayashi, 2007]. Discovery of F. kucerai Rapuzzi et Sama, 2014, described from Shaanxi Province [Rapuzzi \& Sama, 2014], not only brought the first continental Chinese species for the genus, but also it considerably expanded the generic distribution boundary northwards. A new species from eastern Tibet, described here, somewhat fills the gap between the known distributional records of $F$. kucerai and the other two species, $F$. masatakai N.Ohbayashi, 2007 and F. nobuoi Vives et Niisato, 2006, known from Sikkim, India and eastern Nepal, respectively. Furthermore, we are aware of another new, yet undescribed species of this genus from Tibet that has already been mentioned by one of the authors [Miroshnikov, 2014].

This work was supported by a grant No. O529YX5105 from the Key Laboratory of the Zoological Systematics and Evolution of the Chinese Academy of Sciences, and by NSFC programs J1210002 and 31000967.

The material for this paper comes from the following institutional and private collections:

IZAS - Institute of Zoology, Chinese Academy of Sciences, Beijing, China;

MNHN - Muséum national d'Histoire naturelle, Paris, France;

cAM - coll. Alexandr Miroshnikov (Krasnodar, Russia); cCC - coll. Chang-Chin Chen (Tianjin, China); cEV - coll. Eduard Vives (Barcelona, Spain);

cNO - coll. Nobuo Ohbayashi (Kamimiyada, Miura City, Japan);

cWB - coll. Wen-Xuan Bi (Shanghai, China).

Formosotoxotus gressitti Miroshnikov et Lin, sp.n. Figs $1-3,5,10-12$

MATERIAL. China, Xizang (Tibet) Province: holotype $0^{7}$ (IZAS, IOZ(E) 1905132), Linzhi Distr., Bomi, Tongmaizhen, 3006'09" N, $95^{\circ} 04^{\prime} 47^{\prime \prime}$ E, $2060 \mathrm{~m}, 14$.VIII.2012, light trap, leg. Gan-Yan Yang; paratype $\sigma^{7}$ (IZAS, IOZ(E) 1905133), same label; paratype $O^{7}$ (cAM, ex IZAS, IOZ(E) 1905134), same label; 2 paratype $0^{7} O^{7}$ (IZAS, IOZ(E) 1905135 \& 1905297), same locality, but $2070 \mathrm{~m}$, 29.VIII.2006, leg. Ming Bai.

The type series includes also the paratypes either studied by their pictures alone or examined by Wen-Xuan $\mathrm{Bi}$. Chang-Chin Chen or Nobuo Ohbayashi: 5 paratypes $O^{7} O^{7}(\mathrm{cCC})$, same locality as holotype, but with $2100 \mathrm{~m}, 29$.VIII.2005, leg. Song; 2 paratypes $\sigma^{7} \sigma^{7}(\mathrm{cNO})$, same label; 2 paratypes $\sigma^{7} \sigma^{7}(\mathrm{cWB})$, same label; 2 paratypes $O^{7} O^{7}$ (cCC), same label, but with 30.VIII.2005; 51 paratypes $O^{7} O^{7}$ (cCC), same locality, but with 22.VIII.2011, leg. Hai-Lin Yang \& Jian-Yun Wang; 2 paratypes $\bigcirc^{7} \sigma^{7}$ (will be stored in IZAS), same label; 2 paratypes $O^{7} \sigma^{7}$ (will be stored in cAM), same 
label; 4 paratypes $\sigma^{7} \sigma^{7}(\mathrm{cNO})$, same label; 2 paratypes $\sigma^{\top}$ and $O$ (cWB), Bomi, Pailong, 2000 m, 2.IX.2011, leg. Wen-Xuan Bi; 2 paratypes $\sigma^{7} \sigma^{7}$ (cCC), Bomi, Suotong, 2065 m, 14.VIII.2012, leg. Xiao-Dong Yang; 2 paratypes $\sigma^{7} \sigma^{7}(\mathrm{cNO})$, same label.
COMPARATIVE MATERIAL. Formosotoxotus masatakai N. Ohbayashi, 2007: holotype $\sigma^{7}$ (Fig. 6) (MNHN), "Mus.Hist.Nat., Harmand, Sikkim, 1890", "Holotype Formosotoxotus masatakai N. Ohbayashi, 2007" (Fig. 7); Formosotoxotus nobuoi Vives et Niisato,
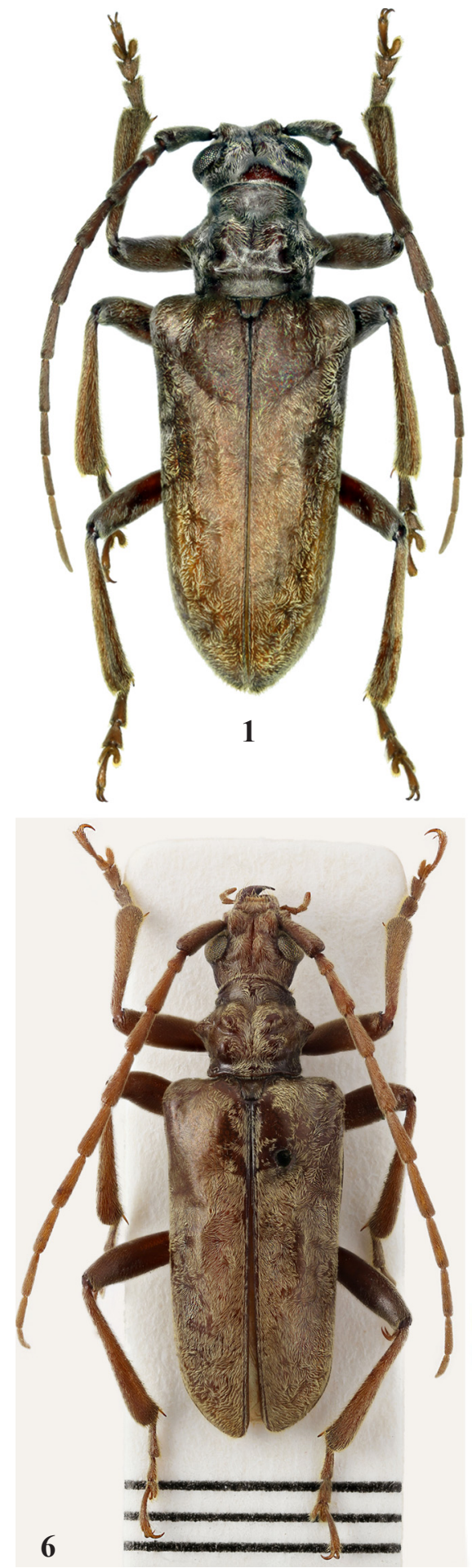

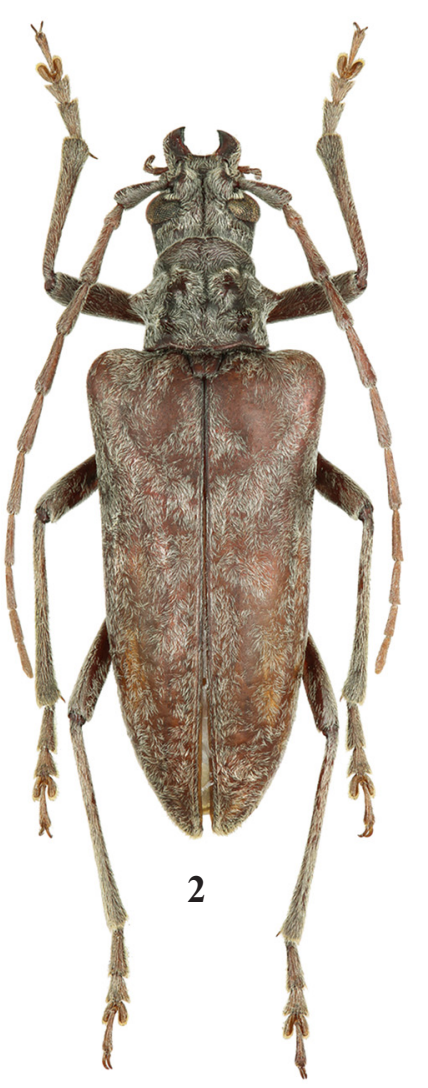

3
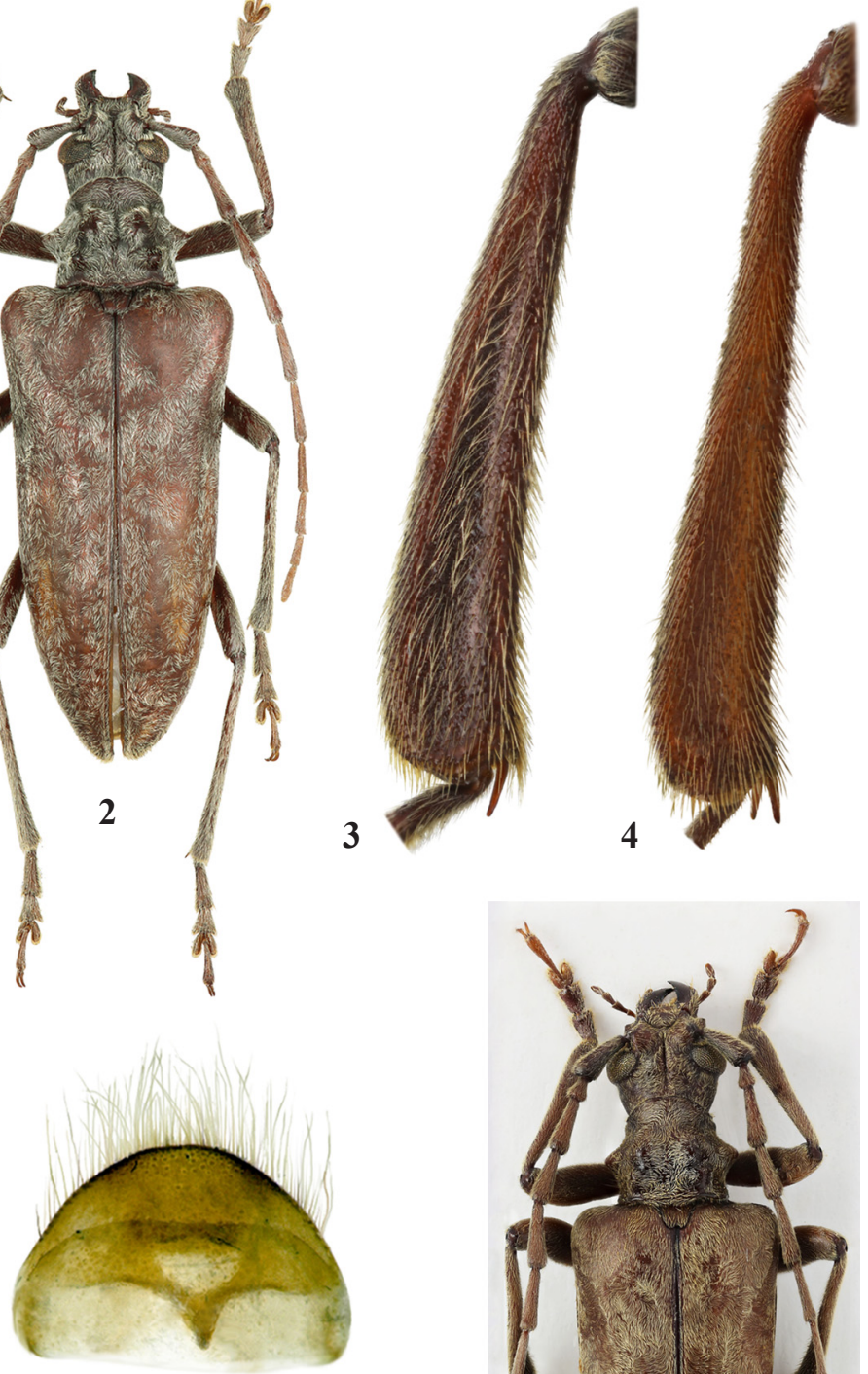

5

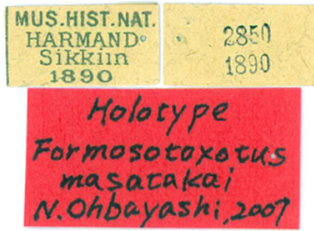

7

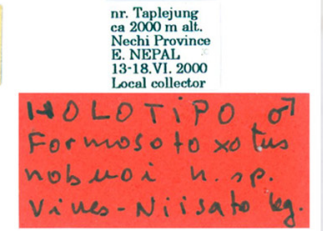

9

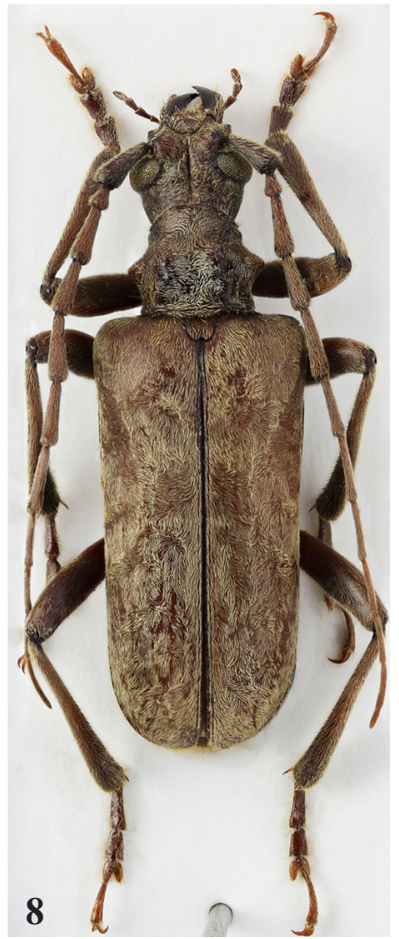

Figs 1-9. Formosotoxotus ssp.: 1-3,5-F. gressitti sp.n.; 4, 6-7-F. masatakai; 8-9-F. nobuoi; 1, 3-6, 8- holotypes males; 2 paratype female (photograph by W.-X. Bi); 3-4 - left metatibia, inner view; 5 - tergite 8 , dorsal view; 7, 9 - labels of the holotype.

Pис. 1-9. Formosotoxotus ssp.: 1-3, 5-F. gressitti sp.n.; 4, 6-7 - F. masatakai; 8-9-F. nоbuoi; 1, 3-6, 8- голотипы, самецы; 2 - паратип, самка (фотография В. Би); 3-4 - левая задняя голень, вид с внутренней стороны; 5 - 8-й тергит, вид сверху; 7, 9 этикетки голотипа. 
2006: holotype OT $^{7}$ (Fig. 8) (cEV), "nr. Taplejung ca, $2000 \mathrm{~m}$ alt., Nechi Province, E. Nepal, 13-18.VI.2000, local collector", "Holotipo $\sigma^{7}$ Formosotoxotus nobuoi Vives - Niisato leg. (Fig. 9); paratype female (cEV), same geographical label.

DIAGNOSIS. Formosotoxotus gressitti sp.n. seems to be especially similar to $F$. masatakai, but differs clearly in the structure of all tibiae (at least so in the male), less strongly developed antennal tubercles, evidently deeper median dorsal groove on the head, more strongly transverse pronotum with more strongly developed tubercles on its disk, more strongly convex tuberculiform elevation at the base of elytra, somewhat different form of tarsomere 2, more strongly elongated antennomeres 2 and 3, different form of tergite 8 , and usually darker body coloration. A new species can also be compared to $F$. nobuoi, from which it differs in more robust body, more strongly narrowed towards the apex and less strongly elongated elytra, shorter antennae, as well as (as and from $F$. masatakai) in the structure of tibiae, in the more strongly convex tuberculiform elevation at the base of elytra, as well as in different shape of the pronotum, tarsomere 2 and tergite 8 . F. gressitti sp.n. differs from $F$. kucerai at least in the form of the pronotum, structure of tibiae, coloration of the body integument and setation.

DESCRIPTION. Male (Fig. 1). Body length 11.6-18.0 $\mathrm{mm}$, humeral width $4.0-6.3 \mathrm{~mm}$. Dark reddish-brown, sometimes mostly reddish-brown.
Head with well-developed antennal tubercles and a sharp deep median groove; with moderately dense, small puncturation; eyes evidently but shallowly emarginate, with large ocelli; genae long, barely shorter than transverse diameter of eye; antennae non-serrate, evidently shorter than body; antennomere 1 subequal in length to $3^{\text {rd }}, 1.08-1.14,0.93-1.03$ or $1.02-1.09$ times as long as $4^{\text {th }}, 5^{\text {th }}$ and $6^{\text {th }}$, respectively; antennomere 2 elongated, $1.30-1.44$ times as long as wide.

Pronotum at level of lateral tubercles $1.19-1.27$ or 1.24 1.33 times as wide as width at base and length, respectively; base 1.15-1.25 times as wide as apex; lateral tubercles welldeveloped; disk with four strong tubercles, the ones at base being obliquely transverse; with small, more or less dense puncturation, mainly on discal tubercles and between them.

Scutellum moderately narrowed towards apex; in length much shorter than width at base; apex truncate; with evident longitudinal median impression.

Elytra 1.96-2.05 times as long as width at base; moderately narrowed towards apex; with distinct longitudinal ribs but unclear puncturation; each elytron at base evidently tuberculiform, elevated; apices of both together rounded.

Prosternal process very narrow between coxae; mesosternal process moderately wide; base of mesosternum with clear dense transverse wrinkles; metasternum and sternites with heterogeneous, mainly small, partly moderately dense puncturation; last (visible) sternite not impressed.
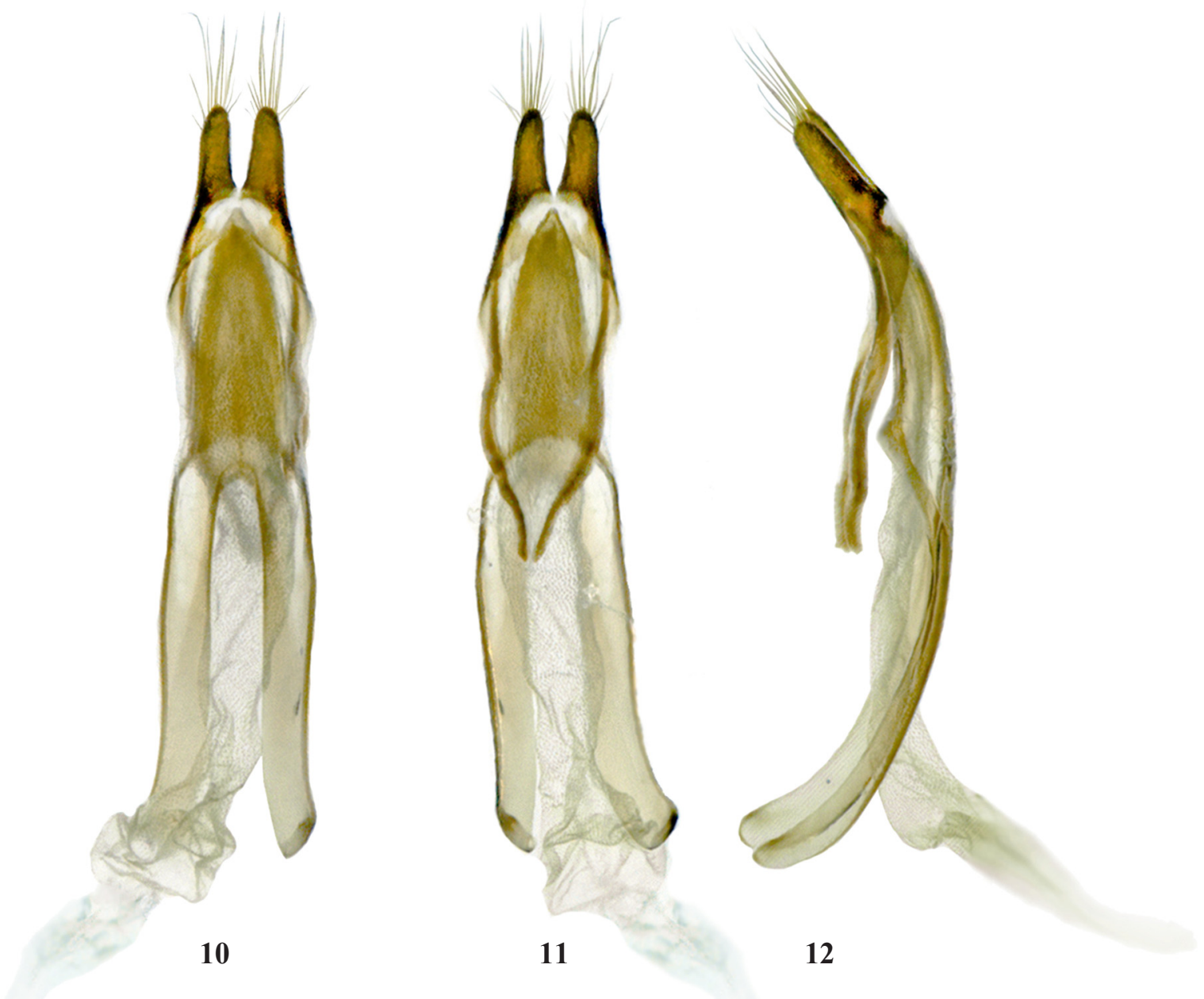

Figs 10-12. Male genitalia of Formosotoxotus gressitti sp.n. (holotype): 10 - dorsal view; 11 - ventral view; 12 - lateral view. Рис. 9-12. Гениталии самца Formosotoxotus gressitti sp.n. (голотип): 10 - вид сверху; 11 - вид снизу; 12 - вид сбоку. 
Legs robust, moderately long; femora not claviform; all tibiae on inner side, meso- and metatibiae on external side, with well-expressed broad longitudinal impression extending throughout apical half and partly on basal half (Fig. 3) (tibiae in F. masatakai - Fig. 4, and F. nobuoi with weak or very weak longitudinal impression); tarsomere 2 of all tarsi strongly broadened from base towards apex, relatively short, width at apex barely shorter than length (tarsomere 2 of all tarsi of $F$. masatakai and $F$. nobuoi moderately broadened from base towards apex, width at apex evidently or much shorter than length). tint.

Recumbent setation well-developed, greyish, with silver

Genitalia (Figs 5, 10-12). Tergite 8 in length much shorter than width at base, apex rounded (in F. masatakai and $F$. nobuoi, tergite 8 at apex widely or narrowly truncate, respectively), with numerous long setae. Median lobe about 1.5 times as long as tegmen, moderately curved; median struts about 0.6 times as long as total length of median lobe; dorsal plate slightly shorter than ventral plate; median foramen not elongated; internal sac without basal armature or rods. Tegmen with lateral lobes about 0.18 times as long as total length; each lobe thick, at apex with long setae.

Female (Fig. 2). Resembles the male, but body slenderer while antennae and legs less robust; body length $17.5 \mathrm{~mm}$, humeral width $6.0 \mathrm{~mm}$.

DISTRIBUTION. Eastern Tibet, China.

ETYMOLOGY. The new species is named in the memory of Dr. Judson Linsley Gressitt, whose centenary is celebrated this year.

Agastophysis meiyingae Miroshnikov, 2014

This species has just been described from Tibet as well [Miroshnikov, 2014]. However, when preparing the layout of the volume for publication which contained the description, a text fragment concerning the studied material was inadvertently omitted. In this connection, the error is corrected with the following missing information given below.

Agastophysis meiyingae has been described, based on the following material (one male only): holotype [IZAS IOZ(E)1905117], China, Xizang Prov., Shannan Distr., Naidong, 1981, leg. Xin-Nian Li \& Bao-Hai Wang. It is this precise locality that must be taken as the locus typicus of the present taxon.

Considering the original description of $A$. meiyingae, it is noteworthy that, although the information about the material was missing, the colour pictures of the holotype and the corresponding figure captions are available, with the necessary references to these pictures given directly in the text [Miroshnikov, 2014, pp. 27, 47, figs 91-92, 98]. In this connection, the holotype designation of $A$. meiyingae, as well as the taxon's validity as quoted in the original description remain unquestioned.

ACKNOWLEDGEMENTS. We are very grateful to Thierry Deuve and Gérard Tavakilian (MNHN) for the opportunity to study the holotype of $F$. masatakai. Eduard Vives (Barcelona, Spain) has kindly provided the holotype and paratype of $F$. nobuoi from his private collection. Our sincere thanks also go to Wen-Xuan Bi, Chang-Chin Chen and Nobuo Ohbayashi for valuable information, as well as again Wen-Xuan Bi for several pictures of the female of $F$. gressitti sp.n. We are deeply indebted to Kirill V. Makarov (Moscow Pedagogical State University, Russia) and Kui-Yan Zhang (IZAS) who kindly helped with the preparation of the habitus photographs of $F$. masatakai and $F$. nobuoi, and the genitalia pictures of $F$. gressitti sp.n., respectively.

\section{References}

Miroshnikov A.I. 2014. New genera and species of the tribe Apatophyseini Lacordaire, 1869 from continental Asia, with notes on the little-known taxa (Coleoptera: Cerambycidae) // A.S. Konstantinov, S.A. Ślipiński \& A.Yu. Solodovnikov (eds.). Advances in studies on Asian cerambycids (Coleoptera: Cerambycidae). Papers by Alexandr I. Miroshnikov, dedicated to the memory of Dr. Judson Linsley Gressitt. Krasnodar-Moscow: KMK Scientific Press Ltd. P.11-50

Ohbayashi N. 2007. A revision of the genus Formosotoxotus (Coleoptera, Cerambycidae, Apatophyseinae), with description of a new species from Sikkim // Elytra. Vol.35. P.194-204.

Rapuzzi P., Sama G. 2014. Descriptions of nine new species of longhorn beetles (Coleoptera: Cerambycidae) // Munis Entomology \& Zoology. Vol.9. No.1. P.1-16. 